\title{
A 3,3'-Diiodothyronine Sulfate Cross-Reactive Material (Compound W), a Potential Marker for Fetal Hypothyroidism
}

\author{
Sing-Yung Wu and William L. Green \\ University of California, Irvine, VA Medical Center, Long Beach, California, and \\ University of Washington, Seattle, Washington \\ USA
}

\section{Introduction}

In developing mammals (including humans), a deficiency or excess of thyroid hormone (TH) in the developing brain during the fetal and neonatal periods can lead to morphological and functional abnormalities (Nunez et al., 1992; Pasquini \& Adamo, 1994; Morreale de Escobar et al., 2004; Harakawa et al., 1989). The most severe form of hypothyroidism in human fetus and neonate is the syndrome of cretinism. Recent studies indicate that abnormalities in intelligence quotient (IQ) and other neuropsychological tests may be found in children of women with subclinical hypothyroidism during pregnancy (Haddow et al., 1999; Mitchell \& Klein, 2004; Casey et al., 2005). Subtle health impairment and reduced socio-educational achievement are observed in young adults with congenital hypothyroidism identified by neonatal screening and subsequently treated (Leger et al., 2011). This suggests the inadequacy in the current strategy with neonatal screening - it may already be too late to secure normal neurological development. Studies of populations indicate that congenital hypothyroidism affects 1 in 3,000 to 4,000 newborns; twice as many females as males. A recent report showed that the incidence in the United States increased from 1:4100 in 1987 to 1:2400 in 2002 (Rastogi \& LaFranchi, 2010; Harris \& Pass, 2007). The causes for this change are not entirely clear even though the screening strategy may have contributed to the increase (Rastogi \& LaFranchi, 2010).

\section{Etiology of congenital hypothyroidism}

Most cases of congenital hypothyroidism are sporadic. But an estimated 15 to 20 percent of cases are inherited including mutations in the DUOX2, PAX8, SLC5A5(NIS), SLC26A4(PDS), TG, TPO, DEHAL1, TSHB, and TSHR genes (Table 1; Rastogi \& LaFranchi, 2010; Grasberger $\&$ Refetoff, 2011). Many inherited cases are autosomal recessive but those with a mutation in the PAX8 gene or certain TSHR gene mutations have an autosomal dominant pattern of inheritance. Another possible cause of fetal hypothyroidism is anti-thyroid medication treatment for maternal hyperthyroidism during pregnancy (Rastogi \& LaFranchi, 2010; Rovet et al., 1999; Mirabella et al., 2000; Vanmiddlesworth et al., 2011). In severe iodinedeficient regions, the prevalence of cretinism can reach $10 \%$ of the local population; WHO 
estimates indicate a prevalence in the millions worldwide (World Health Organization [WHO], 2004; WHO et al., 2007).

\begin{tabular}{|c|c|c|c|}
\hline Category & Etiology & Mechanism & Note \\
\hline \multirow[t]{4}{*}{ Thyroid Failure } & $\begin{array}{l}\text { Developmental } \\
\text { Anomaly }\end{array}$ & Dysgenesis & $\begin{array}{l}98 \% \text { unknown; others } \\
\text { associated genetic } \\
\text { mutation: TTF, NKX2.1, } \\
\text { NKX2.5, PAX-8 }\end{array}$ \\
\hline & Impaired production & $\begin{array}{l}\text { Mutations on TH } \\
\text { synthesis }\end{array}$ & $\begin{array}{l}\text { NIS**, Peroxidase } \\
\text { (DUOX2, DUOXA2), } \\
\text { Pendred syndrome, Tg, } \\
\text { Iodotyrosine deiodinase } \\
\text { (DEHAL1, SECISBP2) }\end{array}$ \\
\hline & TSH Binding & Receptor defect & \\
\hline & TSH Signaling & G-protein & \\
\hline \multirow{4}{*}{$\begin{array}{l}\text { Secondary } \\
\text { Hypothyroidism }\end{array}$} & TSH Recetor & TSH $\beta$ & \\
\hline & TRH & Synthetic defect & $\begin{array}{l}\text { PSIS**, Hypothalamic } \\
\text { lesion }\end{array}$ \\
\hline & & Resistance & Receptor mutation \\
\hline & $\begin{array}{l}\text { Pituitary } \\
\text { development/ } \\
\text { function }\end{array}$ & $\begin{array}{l}\text { Deficient } \\
\text { transcription } \\
\text { factors }\end{array}$ & $\begin{array}{l}\text { HESX1, LHX3, LhX4, PIT1, } \\
\text { PROP1 gene mutations }\end{array}$ \\
\hline \multirow[t]{2}{*}{\begin{tabular}{|l|} 
Peripheral Tissue \\
\end{tabular}} & TH resistance & TSH $\beta$ & \\
\hline & Transporter & $\begin{array}{l}\text { Abnormal TH } \\
\text { transporter }\end{array}$ & MCT8 mutation \\
\hline \multirow[t]{4}{*}{ Transient } & $\begin{array}{l}\text { Antithyroid } \\
\text { medication }\end{array}$ & $\begin{array}{l}\text { Maternal } \\
\text { Hyperthyroidism }\end{array}$ & \\
\hline & Antibodies & Autoimmune & TSHR blocking antibody \\
\hline & Iodine & $\begin{array}{l}\text { Excess or } \\
\text { deficient }\end{array}$ & $\begin{array}{l}\text { Endemic goiter, a major } \\
\text { world health problem }\end{array}$ \\
\hline & $\begin{array}{l}\text { Hepatic } \\
\text { Hemangioma }\end{array}$ & $\begin{array}{l}\text { Excess TH } \\
\text { degradation }\end{array}$ & Type III deiodinase \\
\hline \multirow{2}{*}{$\begin{array}{l}\text { Associate with } \\
\text { other } \\
\text { Abnormalities } \\
\end{array}$} & Cleft palate & & TTF-2 mutation \\
\hline & $\begin{array}{l}\text { Respiratory distress, } \\
\text { Benign Chorea }\end{array}$ & Choreoathetosis & NKX2.1/TTF-1 mutation \\
\hline
\end{tabular}

** NIS: Sodium-iodide symporter; ** PSIS: pituitary stalk interruption syndrome

Table 1. Causes of Congenital Hypothyroidism

Concerns regarding fetal hypothyroidism and timely treatment warrant close monitoring of fetal thyroid status. One method, cordocentesis, is invasive and has a fetal loss rate of 0.5 to 1\% (Daffos, 1989). Recently, ultrasonography has been utilized to assess the fetal thyroid 
gland (Harris \& Pass, 2007; Polak \& Van Vliet, 2010; Luton et al., 2005; Abuhamad et al., 1995; Ribault et al., 2009). Cordocentesis and serial ultrasonographic measurements are either invasive or laborious. The development of a convenient non-invasive means to monitor fetal thyroid function is definitely needed.

\section{Alternate pathways of lodothyronines}

The alternate pathways of thyroid hormone metabolism include conjugation (sulfation or sulfonation, and glucuronidation of the phenolic hydroxy group) and, to a lesser extent, oxidative deamination of the alanine side-chain leading to the formation of the corresponding iodothyroacetates and ether link cleavage (Fig. 1; Wu et al., 2005).

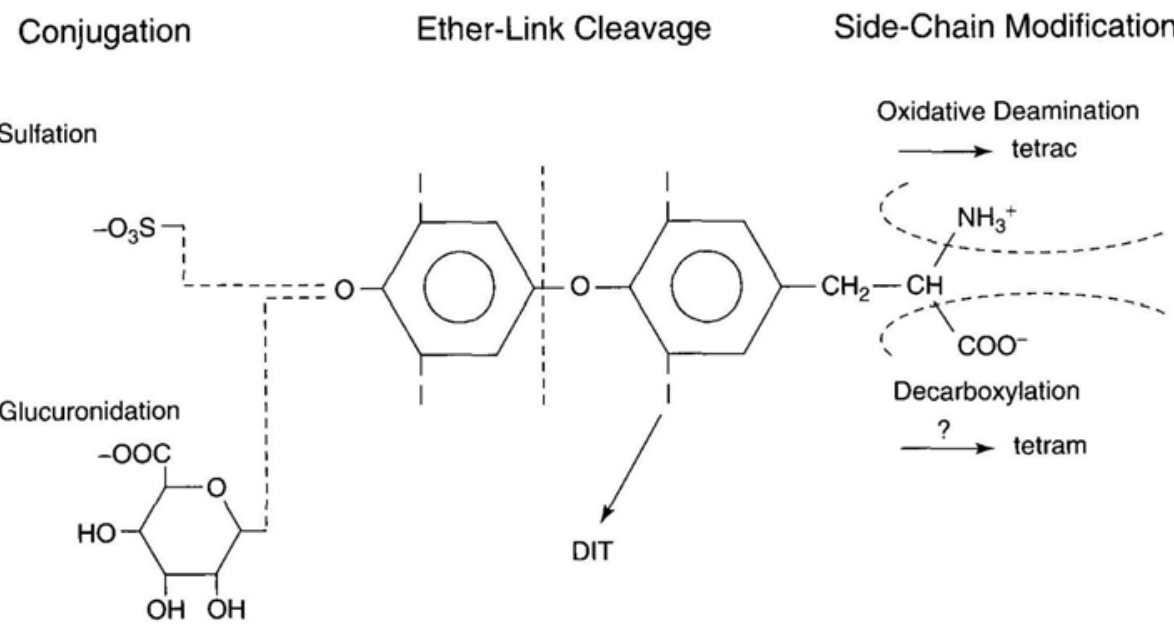

Fig. 1. Alternate pathways of thyroid hormone metabolism. The alternate pathways of thyroid hormone metabolism include conjugation (sulfation or sulfonation, and glucuronidation) and oxidative deamination of the alanine side-chain leading to the formation of the corresponding iodothyroacetates and ether link cleavage. DIT: diiodotyrosine; tetrac: tetraiodothyroacetic acid; tetram: tetraiodothyronamine.

Alternate pathways may serve as mechanisms for further regulation of the bioavailabilities of thyroid hormones in tissues, in addition to deiodination in various physiological and pathophysiological states. Sulfoconjugation of iodothyronines, for example, is an important pathway in developing mammals (Wu et al., 2005); and sulfated iodothyronines can also be deiodinated, even at a faster rate. Likewise, iodothyroacetates can be sulfated and further deiodinated. Iodothyronine glucuronides are rapidly excreted in the bile. Furthermore, sulfoconjugation and glucuronidation are not irreversible pathways for thyroid hormone metabolism. Glucuronides can be hydrolyzed in the intestine and reabsorbed, and sulfoconjugates can be desulfated in selective tissues, e.g. liver and brain, and become available to nuclear receptors, especially in fetuses where type I deiodinase (D1) activity is low. The in vivo occurrence of the decarboxylated metabolites of $T_{4}$ and $T_{3}, 3,3^{\prime}, 5,5^{\prime}-$ 
tetraiodothyronamine $\left(\mathrm{T}_{4} \mathrm{AM}\right)$, and 3,3'5-triiodothyronamine $\left(\mathrm{T}_{3} \mathrm{AM}\right)$ have not been demonstrated (Leonard \& Kohrle, 2000). However, recently, 3-monoiodothyronamine (3monoam or $\left.3-\mathrm{T}_{1} \mathrm{AM}\right)$ and thyronamine $\left(\mathrm{T}_{0} \mathrm{AM}\right)$ have been identified in brain and other tissues in rodents (Scanlan et al., 2004); monoam was found to have rapid effect on reducing rectal temperature in mice and is a potent agonist of the $G$ protein-coupled trace amine receptor TAR1 (Scanlan, 2009). A single dose of $T_{1} A M$ administered to rodents induces a hypometabolic state that in certain ways resembles hibernation. Monoam may be derived from low iodinated iodothyronines by aromatic amino acid decarboxylase (Fig. 1 \& 2), however, its role in developing mammals is not known.

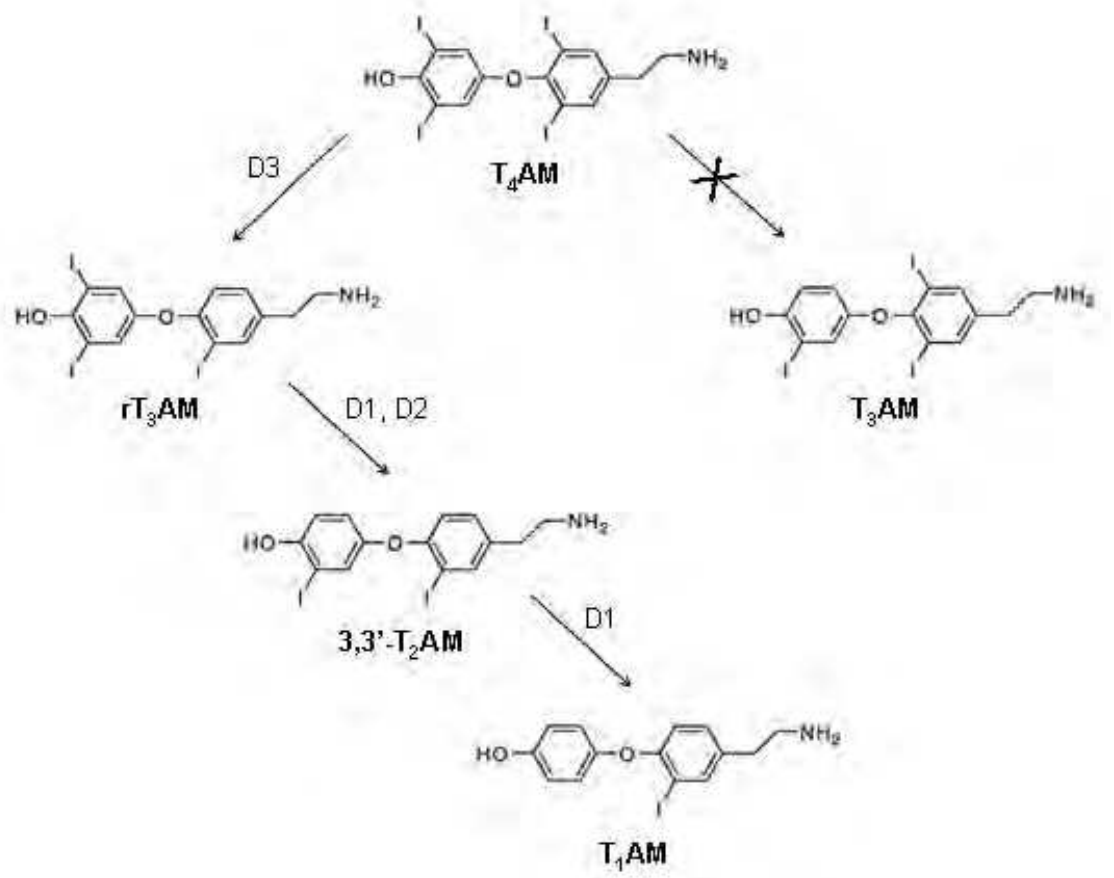

Fig. 2. Postulated $\mathrm{T}_{1} \mathrm{AM}$ (monoam) formation. $\mathrm{T}_{4} \mathrm{AM}$ is not a substrate for type I or II deiodinase (D1 or D2) and cannot be deiodinated to $\mathrm{T}_{3} \mathrm{AM}$. However, $\mathrm{T}_{4} \mathrm{AM}$ is readily deiodinated to $\mathrm{rT}_{3} \mathrm{AM}$ by $\mathrm{D} 3$, and $\mathrm{rT}_{3} \mathrm{AM}$ can be further deiodinated to ultimately provide $\mathrm{T}_{1} \mathrm{AM}$. This suggests a unique biosynthetic deiodination pathway for $\mathrm{T}_{1} \mathrm{AM}$ starting from the decarboxylation products of either $\mathrm{T}_{4}$ or $\mathrm{rT}_{3}$.

\section{Sulfoconjugation of lodothyronines}

Sulfoconjuation has been found to be a major pathway for thyroid hormone metabolism in mammalian fetuses (Fig. 1; Burrow et al., 1994; Wu et al., 2005; Simpson et al., 2005). The sulfation of thyroxine $\left(\mathrm{T}_{4}\right)$ and triiodothyronine $\left(\mathrm{T}_{3}\right)$ and their metabolites [reverse $\mathrm{T}_{3}\left(\mathrm{rT}_{3}\right)$ and 3,3'- diiodothyronine $\left(\mathrm{T}_{2}\right)$ ] may accelerate their further degradation and excretion. The sulfation of $\mathrm{T}_{4}$ completely blocks the outer-ring deiodination to $\mathrm{T}_{3} \mathrm{~S}$. In addition, sulfated 
iodothyronines may serve as a reservoir for biologically active hormones such as $\mathrm{T}_{3}$, which can be recovered from $T_{3} S$ by sulfatases in selective tissues (Wu et al., 2005).

By far, $T_{2}$ is the preferred substrate for various mammalian sulfotransferases (SULTs). The purpose of rapid sulfation of $T_{2}$, as well as $\mathrm{rT}_{3}$ in some tissues studied, is unknown. It is interesting that $T_{2}$ has been found to stimulate mitochondrial respiration in various rat tissues (Moreno et al., 1997) and $\mathrm{rT}_{3}$ may play a role in regulating actin polymerization in brain cells (Leonard \& Farwell, 1997). Also, sulfated $T_{2}$ is the preferred substrate for both human and rat arylsulfatase (ARS) in the microsomal fraction of liver and placenta (Wu et al., 2005). Thus, the possibility that these $T_{4}$ metabolites may play a physiological role in developing animals cannot be excluded.

\section{Sulfoconjugation of lodothyronines and their placental transfer in sheep}

Before the onset of active synthesis and release of $\mathrm{TH}$, iodothyronines detected in the fetus clearly are maternal in origin. This period is approximately the first 17 gestational days (d) in rats, 50d in sheep (Fig. 3) and 90d in humans.

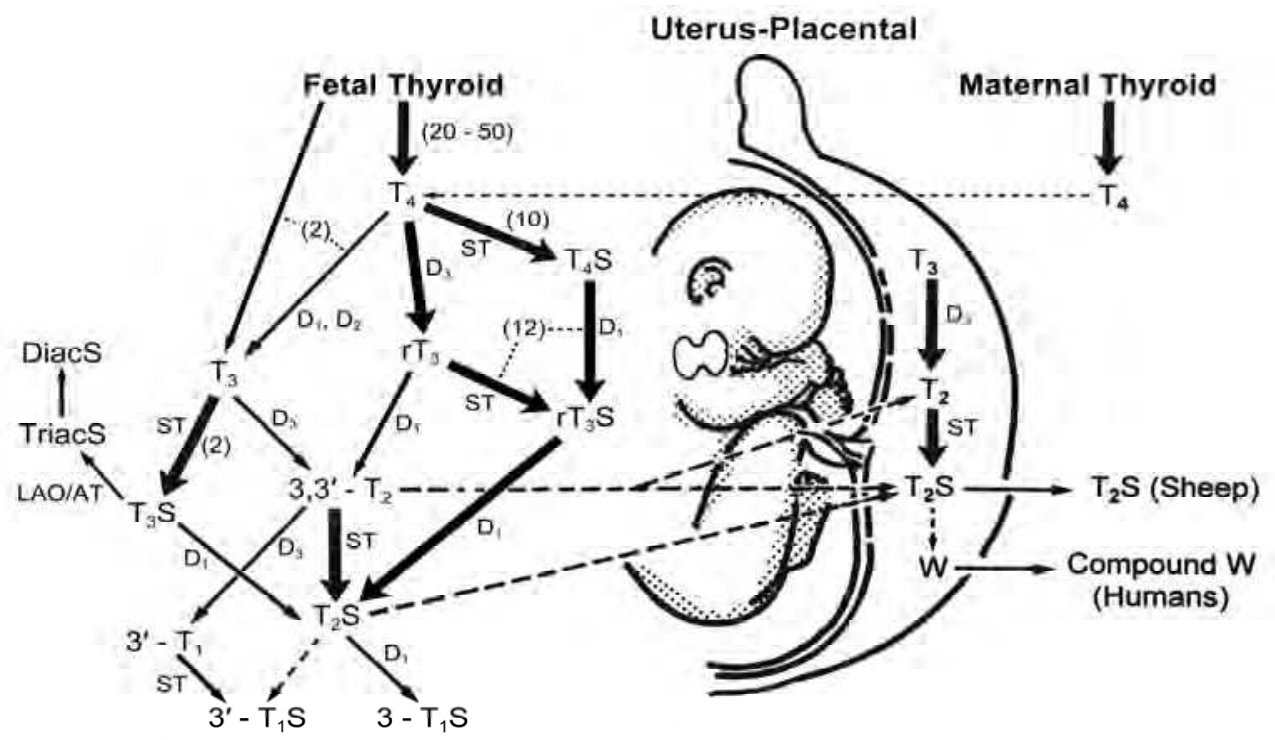

Fig. 3. Postulated metabolic pathways for ovine fetal thyroid hormones. D1, D2, and D3: type I, type II, and type III iodothyronine deiodinases; ST: iodothyronine sulfotransferases (SULT). LAO/AT: L-amino acid oxidase/aminotransferase; DiacS: sulfated 3,3'diiodothyroacetic acid. Heavy solid lines indicate pathways that are more active in fetuses than in adults; thin solid lines, pathways that are less active in fetuses. The upper horizontal light dotted line depicts $\mathrm{T}_{4}$ of maternal origin moving to the fetal compartment in the first trimester, before the fetal thyroid begins functioning. Other broken lines represent unconfirmed pathways. Numbers in parentheses indicate published production rates $(\mu \mathrm{g} / \mathrm{kg} / \mathrm{d})$. 
The proposed scheme for ovine fetal iodothyronine metabolism in late gestation (near term) depicts the production rates for sulfoconjugated thyroid hormone analogs (shown as numbers in parentheses along the thick arrows in Fig. 3). The high production rate (ug/ $\mathrm{kg} / \mathrm{d}$ ) of $\mathrm{T}_{4}$ sulfate $\left(\mathrm{T}_{4} \mathrm{~S}\right)$ reflects the activity of the sulfation pathway. The $\mathrm{rT}_{3} \mathrm{~S}$ production rate likely represents both sulfation of $\mathrm{rT}_{3}$ and inner-ring deiodination of $\mathrm{T}_{4} \mathrm{~S}$. This scheme shown in Fig. 3 also predicts $3,3^{\prime}-\mathrm{T}_{2} \mathrm{~S}$ is a major thyroid hormone metabolite in the fetus.

The transfer of TH and their metabolites may be a two-way street. We have shown high concentrations of sulfated iodothyronine analogs in human and ovine fetal serum. These include $T_{4} S, T_{3} S, r T_{3} S$, and 3,3'- $T_{2} S\left(T_{2} S\right.$ ) (Wu et al., 2005). The high gradient between fetal and maternal serum concentrations of iodothyronine sulfates raises the possibility that there may be significant fetal to maternal transfer of iodothyronine sulfoconjugates. When the ovine fetus was infused with pharmacological amounts $(0.46 \mu$ moles $)$ of $\mathrm{T}_{3}$ or $\mathrm{T}_{3} \mathrm{~S}$, significant fetal to maternal transfer of $\mathrm{T}_{2} \mathrm{~S}$ and $\mathrm{T}_{3} \mathrm{~S}$ occurred (Wu et al., 1995; Wu et al., 1999; Wu et al., 2006). It is noteworthy that significantly more $T_{3} S$ than $T_{2} S$ of fetal origin was recovered in maternal urine following the fetal infusion of either $\mathrm{T}_{3}$ or $\mathrm{T}_{3} \mathrm{~S}$.

Furthermore, maternal $T_{2} S$ and $T_{3} S$ levels were significantly higher after fetal $T_{3}$ than after $\mathrm{T}_{3} \mathrm{~S}$ infusion despite the fact that the mean fetal serum concentration of $\mathrm{T}_{3} \mathrm{~S}$ after fetal $\mathrm{T}_{3} \mathrm{~S}$ infusion was 20 times higher than following $\mathrm{T}_{3}$ infusion (Wu et al., 1995). On the other hand, after fetal infusion of ${ }^{125} \mathrm{I}_{-} \mathrm{T}_{3}$, without disturbing the fetal stable $\mathrm{T}_{3}$ pool, a mean of $19 \%$ of infused radioactive dose was recovered in maternal urine in $4 \mathrm{~h}$. $\mathrm{T}_{2} \mathrm{~S}$, not $\mathrm{T}_{3} \mathrm{~S}$, was identified as the major radioactive iodothyronine in fetal to maternal transfer; only minimal amounts of $\mathrm{T}_{3} \mathrm{~S}$ or $\mathrm{T}_{3}$, were found (Wu et al., 2006).

We also assessed the contribution of fetal $\mathrm{TH}$ to the urinary $\mathrm{T}_{2} \mathrm{~S}$ and $\mathrm{T}_{3} \mathrm{~S}$ pool in ewes. Maternal urinary $\mathrm{T}_{2} \mathrm{~S}$ excretion (pmol/g creatinine) is significantly reduced by fetal thyroidectomy (Tx) but not by maternal Tx (Wu et al., 2001). Maternal urinary $\mathrm{T}_{2} \mathrm{~S}$ excretion correlated positively with fetal serum $T_{4}$ concentrations but not with maternal serum $T_{3}$ or $T_{4}$ levels (Wu et al., 2001). In view of a possible functional role of $\mathrm{T}_{2}$ to stimulate mitochondrial respiration, the removal of $\mathrm{T}_{2}$ from fetal compartment may be necessary for normal maturation of mammalian fetuses (Wu et al., 2005). Furthermore, recent study showed that ARSC, the only sulfatase that hydrolyzes iodothyronine sulfates, has a substrate preference for $T_{2}$ (Kester et al., 2002), which raises the possibility that $T_{2} S$ could be readily reversed back to its precursor, an active iodothyronine. This would suggest a need for the fetus to remove $\mathrm{T}_{2} \mathrm{~S}$ from fetal compartment. Furthermore, in the sheep model, $\mathrm{T}_{2} \mathrm{~S}$ of fetal origin contributes significantly to maternal urinary $\mathrm{T}_{2} \mathrm{~S}$ excretion and may reflect fetal iodothyronine production.

\section{The Evaluation a $T_{2} S$-crossreactive material (compound $w$ ) as a potential marker for fetal thyroid function}

In humans, we found high levels of radioimmunoassayable $\mathrm{T}_{2} \mathrm{~S}$ in maternal serum (Wu et al., 1994) and urine (Wu et al., 1998). Levels increased with the progression of pregnancy and peaked before parturition. At delivery, a 20 -fold increase in serum " $\mathrm{T}_{2} \mathrm{~S}$ " was found compared to non-pregnant women and " $\mathrm{T}_{2} \mathrm{~S}$ " levels returned to non-pregnant values in 7 to 10 days (Fig. 4 \& 5). On closer examination, the radioimmunoassayable " $\mathrm{T}_{2} \mathrm{~S}$ " did not cochromatograph with synthetic $\mathrm{T}_{2} \mathrm{~S}$ by HPLC (Wu et al., 1994). The authentic $\mathrm{T}_{2} \mathrm{~S}$ was 
hydrolyzed by hot-acid digestion (Wu et al., 1994). Using this procedure, the recovery of $\mathrm{T}_{2} \mathrm{~S}$-crossreactive material was near $82 \%$ in fetal and maternal serum (Fig. 6; Wu et al., 2007).

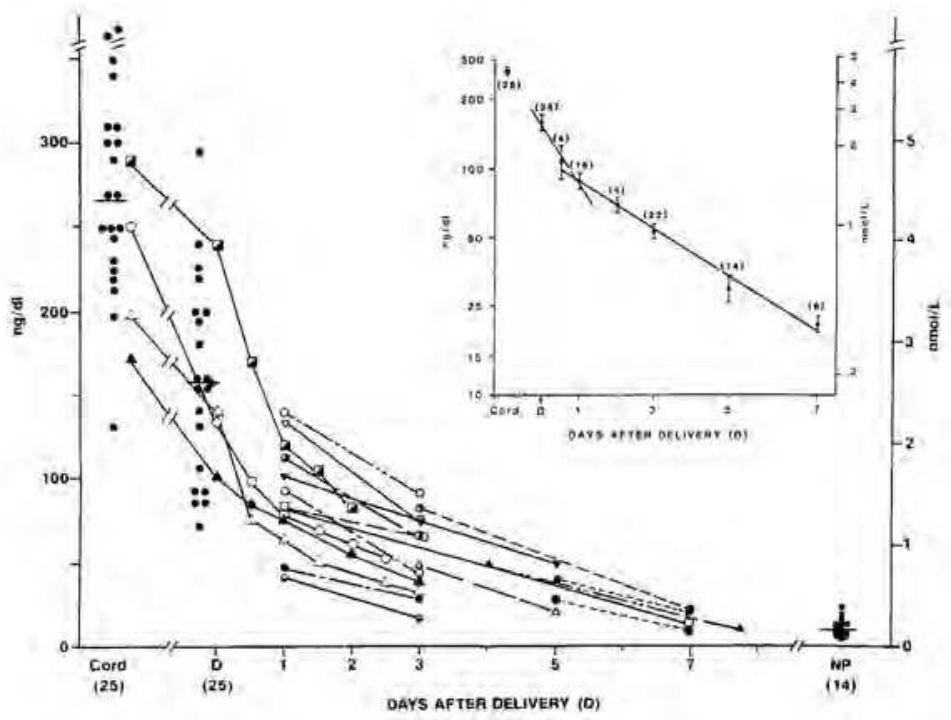

Fig. 4. Change of serum concentrations of compound $\mathrm{W}$ in cord and maternal serum. Compound $\mathrm{W}$, expressed as $\mathrm{ng} / \mathrm{dl}$ of $\mathrm{T}_{2} \mathrm{~S}$, in newborns and maternal serum samples at the time of delivery (D). The connected lines represent serial measurements in the same patients (n $=18$ ). $\mathrm{T}_{2} \mathrm{~S}$ concentrations also were measured in 14 nonpregnant women (NP) for comparison. The decrease in serum compound $\mathrm{W}$ concentrations after parturition is depicted in the semilog plot in the inset. The closed circles and vertical bars represent the mean \pm SEM and (n) represents the total number of samples studied at each time period in a total of 35 patients.

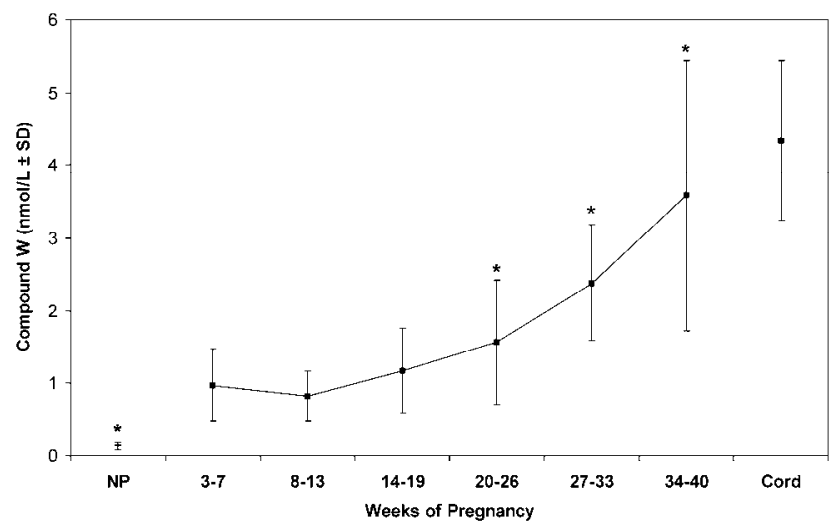

Fig. 5. Changes of compound $W$ at different gestation periods. Normal values of $\mathrm{T}_{2} \mathrm{~S}-$ crossreactive material (compound $\mathrm{W}$ ) in serum from pregnant women, nonpregnant women $(\mathrm{NP})$, and newborns. Vertical bars are mean \pm 1 SD. ${ }^{*} \mathrm{p}<0.05 \mathrm{cf}$. 3-7 weeks pregnancy. 

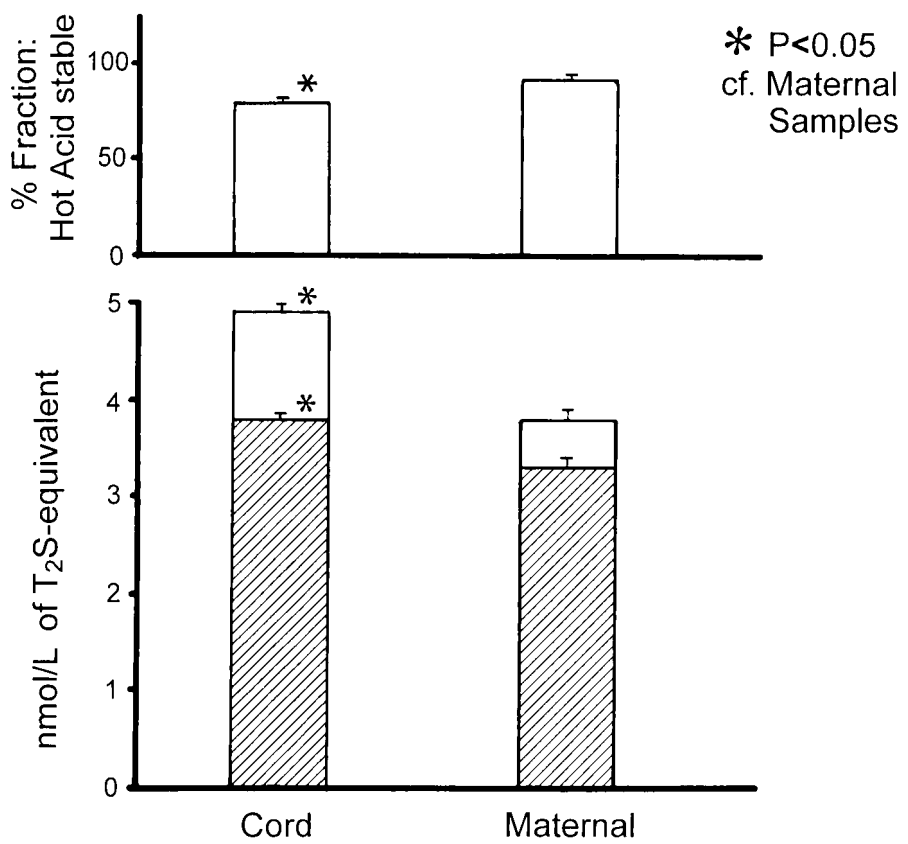

Fig. 6. Recovery of $\mathrm{T}_{2} \mathrm{~S}$-crossreactive material following hot-acid treatment. Top: Percent of $\mathrm{T}_{2} \mathrm{~S}$-crossreactive fraction that is hot-acid stable in cord $(n=6)$ and maternal $(n=12)$ serum samples.

The maternal and paired cord serum concentrations of $\mathrm{T}_{2} \mathrm{~S}$-reactive material presented were adjusted by this percentage to obtain the hot-acid-resistant $\mathrm{T}_{2} \mathrm{~S}$-equivalent activity, or the "corrected" value. Over 40 known synthetic thyroid hormone analogs were examined and none was found to be identical to the $\mathrm{T}_{2} \mathrm{~S}$-like material in pregnant women's serum. Thus, the name Compound $\mathrm{W}$ was given. It is postulated that $\mathrm{W}$ is a side-chain modification of $\mathrm{T}_{2} \mathrm{~S}$, which cross-reacts with $\mathrm{T}_{2} \mathrm{~S}$ antibody but is slightly more hydrophobic than $\mathrm{T}_{2} \mathrm{~S}$. A possible candidate is N, N-dimethylated $\mathrm{T}_{2} \mathrm{~S}$ (Fig. 7; Wu et al., 2007).

To explore the possible origin of compound $\mathrm{W}$, the serum concentrations of sulfated iodothyronines from cord arterial and venous samples were compared. There were no significant differences between the mean $T_{3} S, T_{4} S$, or $\mathrm{rT}_{3} \mathrm{~S}$ concentrations of arterial and venous serum samples. However, the venous $\mathrm{T}_{2} \mathrm{~S}$-equivalent concentration was higher than arterial in seven of the paired samples and lower in two. The mean "corrected" W concentration in paired arterial/venous cord serum was found to be significantly higher in venous samples than in arterial samples (Wu et al., 2007). In addition, the mean of the maternal serum concentrations of $\mathrm{T}_{2} \mathrm{~S}$-reactive material was significantly lower than that of the paired cord serum concentrations. The rapid disappearance of $\mathrm{W}$ from maternal serum immediately after delivery supports this hypothesis (Wu et al., 1994). A similar disappearance slope of serum W was also found in newborn infants (Chen et al., 2010). These findings support the postulation that $\mathrm{W}$ is produced in the placenta. 


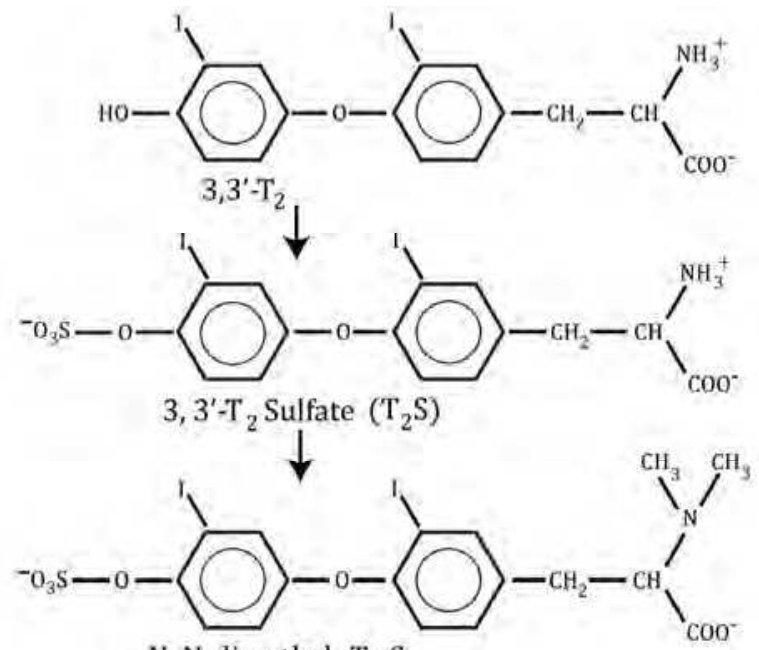

$\mathrm{N}, \mathrm{N}$-dimethyl- $\mathrm{T}_{2} \mathrm{~S}$

Fig. 7. Postulated pathway converting $\mathrm{T}_{2} \mathrm{~S}$ to N, N-methyl- $\mathrm{T}_{2} \mathrm{~S}$. N, N-methyl- $\mathrm{T}_{2} \mathrm{~S}$ has the same physico-chemical characteristics on HPLC and reaction to $\mathrm{T}_{2} \mathrm{~S}$-specific antibody.

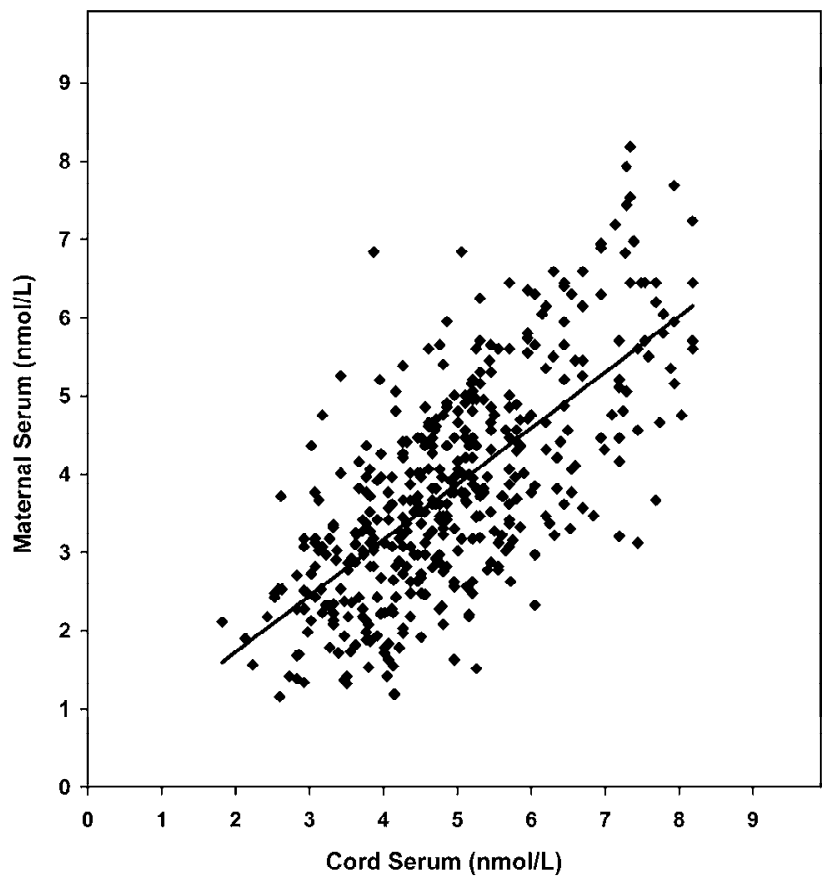

Fig. 8. Levels of $\mathrm{T}_{2} \mathrm{~S}$-crossreactive material in paired maternal and cord serum at term. The solid line is the trend-line from lineal regression analysis for the correlation $(\mathrm{n}=436, \mathrm{R}=0.686)$. 
Prior studies suggest strongly that compound $\mathrm{W}$ is a metabolite of fetal thyroid hormone capable of transplacental fetal to maternal transfer (Wu et al., 2005; Wu et al., 1994; Cortelazzi et al., 1999; Wu et al., 2007). Both maternal and fetal compound W levels increase progressively during gestation with significant direct correlation (in both mothers and fetuses). Additionally, in 436 paired cord and maternal sera obtained at delivery, a highly significant positive correlation was observed between fetal and maternal compound W (Fig. 8). A significant positive correlation was also observed between serum levels of fetal compound $\mathrm{W}$ and fetal $\mathrm{FT}_{4}$ and between maternal and fetal compound $\mathrm{W}$ (Fig. 9; Cortelazzi
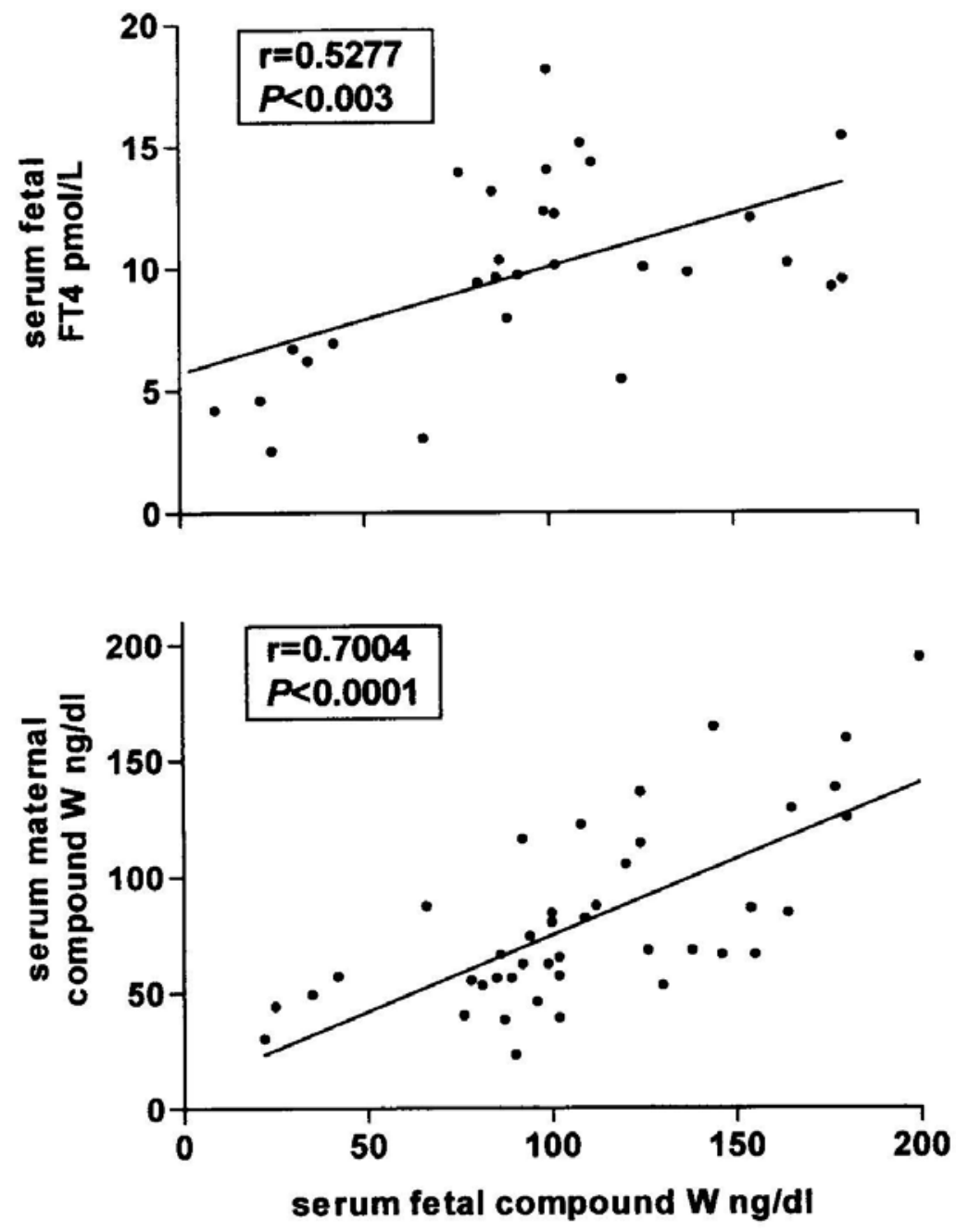

Fig. 9. Compound W levels in fetal serum: correlation with serum fetal FT4 $(n=29)$ and maternal compound $W(n=42)$. [Cortelazzi et al., 1999, reproduced with permission from European J. Endocrinology] 
et al., 1999) whereas no correlation was observed between maternal serum compound W and maternal serum $\mathrm{FT}_{4}$ in euthyroid or hyperthyroid women. Furthermore, maternal compound $\mathrm{W}$ levels seem to reflect the effects of drugs on fetal thyroid function (Cortelazzi et al., 1999). In women on propylthiouracil (PTU), maternal compound W levels were in the low normal range and did not show the usual increase with progression of gestation (Cortelazzi et al., 1999). The lack of progression in maternal compound W levels was confirmed in a recent study of 22 pregnant women treated with anti-thyroid medication (Fig. 10; Vanmiddlesworth et al., 2011). A significant increase in maternal compound W was observed when the PTU dose was decreased or discontinued.

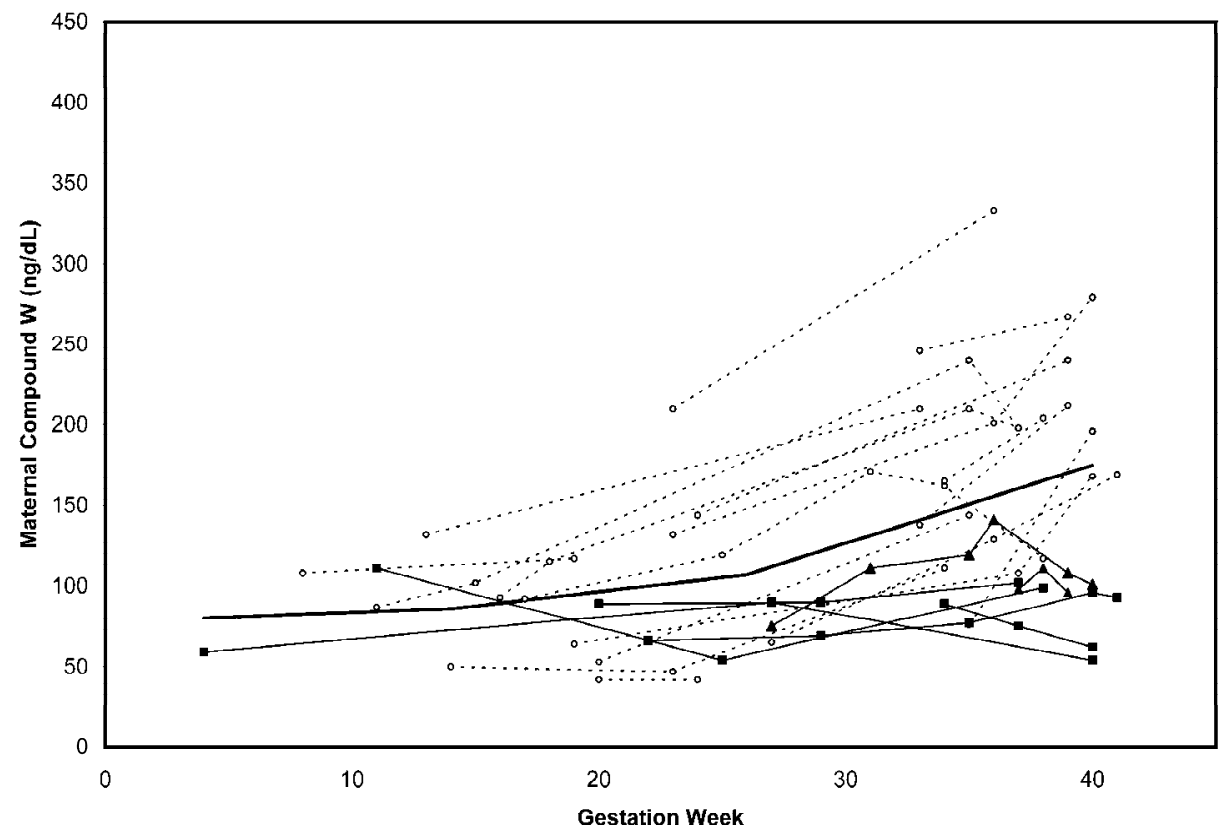

Fig. 10. Courses of compound $\mathrm{W}$ in serum of pregnant patients with hyperthyroidism receiving antithyroid therapy. Two or more points on dotted lines mark the course of compound $\mathrm{W}$ in each patient, and the thick continuous black line shows the marginal mean course. Thick gray lines represent the $10^{\text {th }}$ (lower) and 90th (upper) percentiles. Square markers on solid lines indicate suppressed or nonprogressive serial measurements in 5 patients; triangular markers on solid lines denote 2 patients who had transient progression and then reduction below the $10^{\text {th }}$ percentile at term.

Cortelazzi, et al. (Cortelazzi et al., 1999) suggest that abnormal thyroid function will be revealed by an absence of the normal rise of compound $\mathrm{W}$ during gestation. In comparison with relatively low incidence of congenital hypothyroidism in this population (Rastogi \& LaFranchi, 2010; Harris \& Pass, 2007), serial measurements of compound W in maternal serum can be considered a safe and practical test for the assessment of fetal thyroid function, particularly in hyperthyroid women treated with anti-thyroid drugs, 
whose fetuses can become hypothyroid due to the transplacental passage of the drug (Fig. 10; Vanmiddlesworth et al., 2011).

Further study is needed to include compound W levels in a greater number of hyperthyroid pregnant women treated with anti-thyroid medication or pregnant women with evidence of autoimmune thyroid illnesses, followed by long-term follow-up of psychomotor development in these seemingly euthyroid babies. Suppressed W levels may help to define the sub-group of children exposed to PTU in utero or born to mothers with autoimmune disease who have been shown to have an adverse cognitive outcome (Grasberger \& Refetoff, 2011; Rovet et al., 1999; Mirabella et al., 2000; Mitchell \& Klein, 2004; Casey et al., 2005).

\section{Conclusion}

Sulfoconjugation is a major metabolic pathway for thyroid hormone in developing mammals. The significant rise of sulfated iodothyronines in mammalian fetal compartments raises the possibility that significant fetal to maternal transfer of the conjugates may occur in late gestation as the fetal hypothalamic-pituitary-thyroid system becomes more mature. This transfer may be a novel mechanism to maintain low $T_{3}$ states or regulate serum $T_{2}$, a thermogenic hormone that is important for normal tissue maturity. The possibility that the transferred iodothyronine sulfate, especially $\mathrm{T}_{2} \mathrm{~S}$ and its metabolite, may serve as a marker of fetal thyroid function needs to be further explored.

\section{References}

Abuhamad, A.Z., Fisher, D.A., Warsof, S.L., et al. 1995. Antenatal diagnosis and treatment of fetal goitrous hypothyroidism: case report and review of the literature. Ultrasound Obst Gynecol. 6:368-371.

Burrow, G.N., Fisher, D.A., Larsen, P.R. 1994. Maternal and fetal thyroid function. N Engl J Med. 331:1072-1078.

Casey, B.M., Dashe, J.S., Wells, C.E., McIntire, D.D., Byrd, W., Leveno, K.J., Cunningham, F.G. 2005. Subclinical hypothyroidism and pregnancy outcomes. Obstet Gynecol. 105:239-245.

Chen, D.Z., Yu, H.Y., Bao, J.D., Xue, W., Fisher, D.A., Wu, S.Y. 2010. 3, 3'-diiodothyronine sulfate cross-reactive material (compound $W$ ) in human newborns. 14 International Thyroid Congress, Paris, September 11-16. \#1017.

Cortelazzi, D., Morpurgo, P.S., Azmperini, P., Fisher, D.A., Beck-Peccoz, P., Wu, S.Y. 1999. Fetal Hypothyroidism: New diagnostic and therapeutic approaches. Europ J Endocrinol. 141:570-578.

Daffos, F. 1989. Fetal blood sampling. Ann Rev Med. 40:319-329.

Engler, D., Burger, A.G. 1984. The deiodination of the iodothyroninesand of their derivatives in man. Endocr Rev. 5:151-184.

Grasberger, H., Refetoff, S. 2011. Genetic causes of congenital hypothyroidism due to dyshormononogenesis. Current Opin Pediat. 23:421-428.

Haddow, J.E., Palomaki, G.E., Allan, W.C., Williams, J.R., Knight, G.J., Gagnon, J., O'Heir, C.E., Mitchell, M.L., Hermos, R.J., Waisbren, S.E., Faix, J.D., Klein, R.Z. 1999. Maternal thyroid deficiency during pregnancy and subsequent neuropsychological development of the child. N Engl J Med. 341:549-555. 
Harakawa, S., Akazawa, S., Akazawa, M., Hashimoto, M., Yamashita, S., Izumi, M., Nagataki, S. 1989. Changes of serum thyroid hormone levels induce malformations on early embryogenesis in rats. Acta Endocrinol. 121:739-743.

Harris, K.B., Pass, K.A. . 2007. Increase in congenital hypothyroidism in New York State and in the United States. Mol Genet Metab. 91(3):268-277.

Kester, M.H., Kaptein, E., van Dijk, C.H., Roest, T.J., Tibboel, D., Coughtrie, M.W., Visser, T.J. 2002. Characterization of iodothyronine sulfatase activities in human and rat liver and placenta. Endocrinology. 143:814-819.

Leger, J., Ecosse, E., Roussey, M., Lanoe, J.L., Larroque, B., and the French Hypothyroidism Study Group. 2011. Subtle health impairment and socioeducational attainment in young adult patients with congenital hypothyroidism diagnosed by neonatal screening: a longitudinal population-based cohort study. J Clin Endocrinol Metab. 96:1771-1782.

Leonard, J.L., Farwell, A. 1997. Thyroid hormone-regulated actin polymerization in brain. Thyroid. 7:147-151.

Leonard, J.L., Kohrle, J. 2000. Intracellular pathways of iodothyronine metabolism, In: Bravermen, L.E., Utiger, R.D. (eds), Werner and Ingbars, The Thyroid: A Fundamental and Clinical Text, 8th ed. JB Lippincott, New York, pp. 136-173.

Luton, D., Le Gac, I., Vuillard, E., et al. 2005. Management of Graves' disease during pregnancy: the key role of fetal thyroid gland monitoring. J Clin Endocrinol Metab. 90:6093-6098.

Mirabella, G., Feig, D., Astzalos, E., Perlman, K., Rovet, J.F. 2000. The effect of abnormal intrauterine thyroid hormone economies on infant cognitive abilities. J Pediatr Endocrinol Metab. 13:191-194.

Mitchell, M.L., Klein, R.Z. 2004. The sequelae of untreated maternal hypothyroidism. Eur J Endocrinol. 151 Suppl 3:U45-U48.

Moreno, M., Lanni, A., Lombardi, A., Goglia, F. 1997. How the thyroid controls metabolism in the rat: different roles for triiodothyronine and diiodothyronines. J Physiol. 505:529-538.

Morreale de Escobar, G., Obregon, M.J., Escobar del Rey, F. 2004. Role of thyroid hormone during early brain development. Eur J Endocrinol. 151:U25-U37.

Nunez, J., Couchie, D., Aniello, F., Bridoux, A.M. 1992. Thyroid hormone effects on neuronal differentiation during brain development. Acta Medica Austriaca. 19:36-39.

Pasquini, J.M., Adamo, A.M. 1994. Thyroid hormones and the central nervous system. Develop Neurosci. 16:1-8.

Polak, M., Van Vliet, G. 2010. Therapeutic approach of fetal thyroid disorder. Hormone Research in Paediatrics. 74:1-5.

Rastogi, M.V., LaFranchi, S.H. 2010. Congenital hypothyroidism, Orphanet J Rare Dis. 5:17.

Ribault, V., Castanet, M., Bertrand, A-M. et al. 2009. Experience with intraamniotic thyroxine treatment in nonimmune fetal goitrous hypothyroidism in 12 cases. J Clin Endocrinol Metab. 94:3731-3739.

Rovet, J., Mirabella, G., Arsenault, P., Myszak, M., Feig, D., Kelly, C. 1999. The effect of PTU exposure during pregnancy on infant cognitive development. A prospective study, Program of 72nd Annual Meeting of the Am Thyroid Assoc, Palm Beach, FL p. 33. (Abstract) 
Scanlan, T.S., Suchland, K.L., Hart, M.E., Chiellini, G., Huang, Y., Kruzich, P.J., Frascarelli, S., Crossley, II D.A., Bunzow, J.R., Ronca-Testoni, S., Lin, E.T., Hatton, D., Zucchi, R., Grandy, D.K. 2004. 3-Iodothyronamine is an endogenous and rapid-acting derivative of thyroid hormone. Nat Med. 10:638-642.

Scanlan, T.S. 2009. 3-iodothyronamine (T1AM): A new player on the thyroid endocrine team? Endocrinology 150:1108-1111.

Simpson, J., Williams, F.L., Delahunty, C., van Toor, H., Wu, S.Y., Ogston, S.A., Visser, T.J., Hume, R. 2005. Scottish Preterm Thyroid Group Serum thyroid hormones in preterm infants and relationships to indices of severity of intercurrent illness. J Clin Endocrinol Metab. 90:1271-1279.

Vanmiddlesworth, L., Vanmiddlesworth, N.R., Egerman, R.S., Bush, A.J., Ramsey, R.D., Delmar, L.P., Ho, E.C., Wu, S.Y. 2011. Thyroid function and 3,3'-diiodothyronine sulfate cross-reactive substance (compound $\mathrm{w}$ ) in maternal hyperthyroidism with antithyroid treatment. Endocrine Pract. 17:170-176.

WHO (ed.): Iodine status worldwide: WHO Global Database on Iodine Deficiency. Geneva: World Health Organization, 2004.

WHO, UNICEF, ICCIDD: Assessment of iodine deficiency disorders and monitoring their elimination: a guide for programme managers. Geneva: World Health Organization, 2007.

Wu, S.Y., Fisher, D.A., Huang, W.S., Kuo, S.W., Chen, W.L. 1998. The changes of urinary compound W concentrations in pregnant women. Am J Obst-Gynecol. 178:886-91.

Wu, S.Y., Green, W.L., Huang, W.S., Hays, M.T., Chopra, I. J. 2005. Alternate pathways of thyroid hormone metabolism. Thyroid. 15:945-960.

Wu, S.Y., Huang, W.S., Fisher, D.A. Florsheim W.H., Kashiwai K., Polk D.H. 2001. 3, 3'diiodothyronine sulfate excretion in maternal urine reflects fetal thyroid function in sheep. Pediat Res. 50:358-364.

Wu, S.Y., Huang, W.S., Ho, E., Wu, E.S.C., Fisher, D.A. 2007. A 3,3'-diiodothyronine sulfate cross-reactive substance, compound $\mathrm{W}$, in serum from pregnant women - a potential marker for fetal thyroid function. Pediatr Res. 61:307-312.

Wu, S.Y., Polk, D.H., Chen, W.L., Fisher, D.A., Huang, W.S., Yee, B. 1994. A 3, 3' diiodothyronine-sulfate cross-reactive compound in serum from pregnant women. J Clin Endocrinol Metab. 78:1505-1509.

Wu, S.Y., Polk, D.H., Fisher, D.A., Huang, W.S., Reviczky, A., Chen, W.L. 1995. Identification of $3,3^{\prime}-\mathrm{T}_{2} \mathrm{~S}$ as a fetal thyroid hormone derivative in maternal urine in sheep. Am J Physiol. 268 (Endocrinol Metab 31):E33-E39.

Wu, S.Y., Polk, D.H., Huang, W.S., Fisher, D.A. 1999. Fetal-to-maternal transfer of 3, 3', 5 triiodothyronine sulfate and its metabolites in sheep. Am J Physiol. 268 (Endocrinol Metab 40):E915-E919.

Wu, S.Y., Polk, D.H., Huang, W.S., Green, W.L., Thai, B., Fisher, D.A. 2006. Fetal-to-maternal transfer of thyroid hormone metabolites in late gestation in sheep. Pediatr Res. 59: 102-106. 


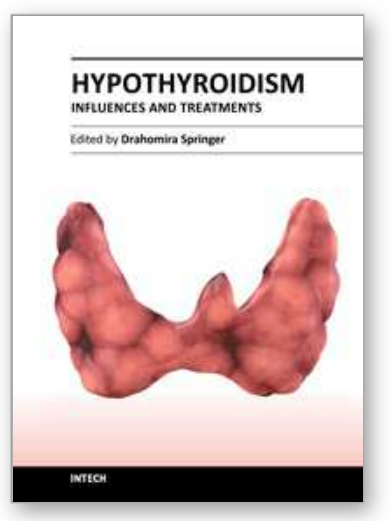

\author{
Hypothyroidism - Influences and Treatments \\ Edited by Dr. Drahomira Springer
}

ISBN 978-953-51-0021-8

Hard cover, 348 pages

Publisher InTech

Published online 08, February, 2012

Published in print edition February, 2012

Hypothyroidism is the most common thyroid disorder and it is significantly more frequent than presented millions of people suffer from this disease without knowing it. People with this condition will have symptoms associated with slow metabolism. Estimates of subclinical hypothyroidism range between 3 to $8 \%$, increasing with age, whereas it more likely affects women than men. About $10 \%$ of women may have some degree of thyroid hormone deficiency. Hypothyroidism may affect lipid metabolism, neurological diseases or other clinical conditions. The book includes studies on advancements in diagnosis, regulation and replacement therapy, thyroid ultrasonography and radioiodine therapy for hypothyroidism. "Hypothyroidism - Influences and Treatments" contains many important specifications, results of scientific studies and innovations for endocrine practice.

\title{
How to reference
}

In order to correctly reference this scholarly work, feel free to copy and paste the following:

Sing-Yung Wu and William L. Green (2012). A 3,3'-Diiodothyronine Sulfate Cross-Reactive Material (Compound W), a Potential Marker for Fetal Hypothyroidism, Hypothyroidism - Influences and Treatments, Dr. Drahomira Springer (Ed.), ISBN: 978-953-51-0021-8, InTech, Available from:

http://www.intechopen.com/books/hypothyroidism-influences-and-treatments/a-3-3-diiodothyronine-sulfatecross-reactive-material-compound-w-a-potential-marker-for-fetal-hypoth

\section{INTECH}

open science | open minds

\section{InTech Europe}

University Campus STeP Ri

Slavka Krautzeka 83/A

51000 Rijeka, Croatia

Phone: +385 (51) 770447

Fax: +385 (51) 686166

www.intechopen.com

\section{InTech China}

Unit 405, Office Block, Hotel Equatorial Shanghai

No.65, Yan An Road (West), Shanghai, 200040, China

中国上海市延安西路65号上海国际贵都大饭店办公楼 405 单元

Phone: +86-21-62489820

Fax: $+86-21-62489821$ 
(C) 2012 The Author(s). Licensee IntechOpen. This is an open access article distributed under the terms of the Creative Commons Attribution 3.0 License, which permits unrestricted use, distribution, and reproduction in any medium, provided the original work is properly cited. 